\title{
Farming and Restoring Oysters to Combat Climate Change
}

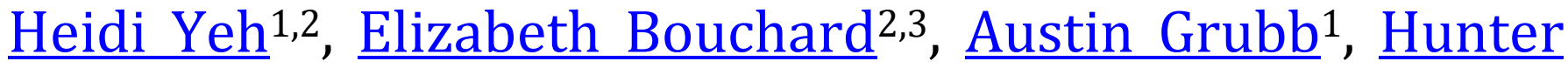 Lanovoi $^{4}$}

${ }^{1}$ Rutgers University School of Environmental and Biological Sciences, Department of Marine \& Coastal Sciences, New Brunswick, NJ

${ }^{2}$ Rutgers New Jersey Agricultural Experiment Station, Haskin Shellfish Research Laboratory, Port Norris, NJ

${ }^{3}$ Rutgers University School of Environmental \& Biological Sciences, Department of Ecology \& Evolution, New Brunswick, NJ

${ }^{4}$ Rutgers Biomedical \& Health Sciences, Department of Pharmacology, Physiology, \& Neuroscience, Newark, NJ https://doi.org/10.38126/ISPG180212

Corresponding Author: Heidi.Yeh@marine.rutgers.edu

Keywords: oysters; restoration; aquaculture: climate change

Executive Summary: To confront the myriad challenges posed by climate change, we present oysters as a nature-based solution with an abundance of environmental benefits and economic stimulus to coastal communities. We encourage the Biden administration to support international efforts to restore oyster reefs by presenting an "Oyster Restoration Initiative" to the World Economic Forum, mirroring recent actions on trees. On the domestic front, several legislative actions can be taken to sustain the current trajectory of restoration efforts. These efforts can be pursued in tandem, but we recommend that policy actions focus on expanding low carbon, oyster-based restorative aquaculture programs. This can revolutionize U.S. food production while reducing pollution from other forms of agriculture.

\section{Environmental benefits of oysters}

Picture an oyster reef: in coastal inlets where saltwater from the ocean mixes with freshwater from rivers, underwater metropolises of oyster shells rise up from the mud. These oysters filter algae and sediments from the water, which provides immediate benefits to coastal waters inundated with nutrient pollution from urban development and land-based agriculture (Bricker, Rice, and Bricker 2014). While rendering the water chemistry more habitable for other organisms, they also provide complex physical structures that serve as habitats for an abundance of worms, sponges, seaweeds, crabs, and fish. Oyster reefs greatly enhance marine biodiversity (Ermgassen et al. 2016; Gregalis, Johnson, and Powers 2009), as areas adjacent to the reef will have an abundance and variety of animals two times greater than shorelines without reefs (Chowdhury et al. 2020). Generations of oysters are cemented together in these reefs, as offspring settle and grow atop their ancestors. In some marine settings, the carbon in oyster shells can be buried under the growth of subsequent generations, serving as a means to sequester carbon indefinitely (Fodrie et al. 2017). The ocean can act as an effective carbon storage reservoir as humans seek to draw down excess greenhouse gasses (GHG) from the atmosphere, ("The Blue Carbon Initiative" 2019). As climate change progresses, oyster reefs can grow at rates that keep pace with rising sea levels (Rodriguez et al. 2014). Due to their stabilizing effect against erosion (Walles et al. 2015; La Peyre et al. 2015), artificial oyster reefs are often incorporated into "Living Shorelines", which are eco-friendly alternatives to hard structures like seawalls (Smith et al. 2020). This ecosystem service will become increasingly valuable as the frequency of high tide flooding and the intensity of hurricanes rise with 
climate change (NOAA Office for Coastal Management 2021).

\section{Oyster habitat loss and restoration}

Before 1800, oyster reefs dominated the majority of temperate coastlines (McAfee and Connell 2020). After decades of unsustainable harvesting, combined with other stressors like disease, habitat destruction, and degraded water quality, these ecosystems have largely been replaced by sparsely-inhabited sand (Beck et al. 2009). Globally, only $15 \%$ of historic oyster reefs are currently intact (Beck et al. 2009), and climate change threatens native oyster populations on the edge of survival. However, the missing $85 \%$ of historic oyster reefs could be viewed as an opportunity: if oysters thrived there once, they can again - they just need help getting started.

Oyster restoration efforts are vital for increasing the area of reef habitat and are an important naturebased solution to climate change. These projects are commonly funded by the government, but restoration activities involve a variety of players, including government agencies, NGOs, scientists, community volunteers, and the oyster industry. Several shellfish reef restoration guides are available from organizations such as the Nature Conservancy and NOAA (Brumbaugh et al. 2006; Leonard and Macfarlane 2011; Fitzsimons et al. 2020; Branigan and Nature Conservancy (Australia) 2019; Baggett et al. 2014; Preston et al. 2020).

\section{Aquaculture contributions to restoration}

Although unsustainable harvesting largely caused the decline of oysters, commercial oyster farming operations (aquaculture) can aid restoration and management efforts. The oyster on your dinner plate was either harvested from a wild oyster fishery or farmed. Aquaculture typically involves growing oysters in bags or cages in natural estuaries, where they provide many of the same benefits as their wild counterparts. It takes two to three years for the average oyster to reach market-size, during which time most will reproduce, sending out larvae that may settle in the surrounding waters. This "spill-over recruitment" can incidentally restore local oyster populations (Mumbles Oyster Company 2021). However, this effect can also present challenges when non-native oyster species are used for restoration or aquaculture. For example, the Pacific oyster
(Magallana gigas) is native to Asia, but its widespread use abroad led to the establishment of wild populations on six continents (McAfee and Connell 2020). Despite its nonnative status, the Pacific oyster can contribute the ecosystem services that are no longer provided by native populations.

The energy and feed inputs for farmed oysters is minimal, rendering it one of the lowest carbon food options available. Livestock are responsible for $14.5 \%$ of human induced GHG emissions (Gerber and Food and Agriculture Organization of the United Nations 2013). Oyster aquaculture releases less than one percent of the GHGs required to produce the same amount of meat from beef, small ruminants, pork, and poultry (Ray et al. 2019). Substituting livestock-derived protein with oysters could have a substantial impact on global GHG emissions.

Seaweed farming can be combined with oyster farming operations to efficiently produce another food with a low environmental impact. In the U.S., the NGO GreenWave provides a model for restorative aquaculture that integrates bivalve aquaculture and seaweed farming (Stuchtey et al. 2020). GreenWave estimates that "regenerative ocean farms" can produce up to 150,000 count shellfish and ten tons of seaweed per acre, with $\$ 90,000$ to $\$ 120,000$ in annual profits (Stuchtey et al. 2020); for comparison, farmers in central Illinois are projected to lose $\$ 32$ per acre of corn harvested despite increased federal aid (Schnitkey et al. 2020). Growing seaweed alongside shellfish provides year-round income and job stability to aquaculture workers, as seaweed and shellfish are harvested at different times of the year (Stuchtey et al. 2020). Seaweed production can further combat climate change; findings in the lab and on the farm indicate that feeding livestock with as little as 0.2 to $3 \%$ dietary algae has the capacity to reduce methane produced from ruminant flatulence by 80 to $98 \%$ with little impact on meat quality (Machado et al. 2016; 2016; Roque et al. 2019; Kinley et al. 2020).

A cap-and-trade-style program might be one viable way to drive oyster restoration in suboptimal waters. A pilot program in Maryland credits growers with the removal of nitrogen and phosphorus in the water column finding that, among several oyster farms, 28 to $457 \mathrm{~kg}$ of $\mathrm{N}$ per acre a year is removed with a 
potential economic value of $\$ 560$ to $12,446,000$ (Parker and Bricker 2020). However, these efforts must be paralleled with actions to mitigate nutrient pollution at the source (Land 2014).

\section{Limitations to expansion}

The long-term benefits to society outweigh the initial restoration costs. The average project cost for oyster restoration is about $\$ 121,405$ per acre, but it is highly variable due to differing goals, construction methods, and site-specific factors (Bersoza Hernández et al. 2018). However, restoration costs should be recovered within two to fourteen years, and the ecosystem services of oyster reefs are valued at $\$ 2,226$ to $\$ 40,064$ per acre per year (Grabowski et al. 2012). This estimate considers services such as protection of coastal property and water quality enhancement, but it excludes oyster harvest. This value may be even greater when commercial oyster harvest via fisheries is also considered, as restoration efforts can lead to the reopening of fisheries.

A large challenge for reef restoration practitioners is government regulation, as a patchwork of permitting processes attempt to balance conservation concerns with public health threats (McCann 2019). Officials worry that oysters illegally harvested from reefs in waters with high concentrations of pathogens might cause shellfish food poisoning (Xu et al. 2015; Ismail et al. 2014). Harvesting is prohibited in areas of low water quality, but poaching remains a threat to uninformed consumers.

Here we will explore how the U.S. can address these challenges while building upon its progress using wild oysters and restorative aquaculture methods, as well as encourage international participation. The policy options presented here can be pursued in tandem by the Biden administration. This memo arranges the options from least ambitious to most.

\section{Policy options}

\section{i. Recommendation 1: Remove impediments to} domestic restoration efforts.

Synergistic effects of removing impediments to domestic restoration efforts could accelerate the annual restoration rate above the current U.S. average annual restoration rate of 470 acres per year
(Bersoza Hernández et al. 2018). This rate could be improved with the following legislative actions:

1) Revive VP Harris' legislation S. 1730 for "Living Shorelines" to make $\$ 50$ million in federal funds available for state and local governments to match for local projects. The companion bill (H.R.3115, introduced by Rep. Frank Pallone) was passed by the House of Representatives.

2) Continue to support the restoration and aquaculture programs of the Sea Grant Association (NOAA), which requires $\$ 122.9 \mathrm{M}$ for FY22 appropriations.

3) Develop a central and transparent reef restoration permitting platform for practitioners that complies with ISSC public health guidelines (Food and Drug Administration 2019) and cooperates with the U.S. Army Corp of Engineers and state regulatory agencies.

4) Appropriate funds to expand access to recently developed rapid tests for detecting shellfish pathogens (Fu et al. 2018). This action will protect vulnerable individuals who consume raw shellfish: immunocompromised populations are typically most affected (CDC 2020). Despite education on associated risks, and the availability of alternatives like post-harvest processed oysters, consumers prefer to consume raw oyster products (Bruner et al. 2014).

5) Develop a national cap-and-trade style program with a timely goal set to reduce the cap on nutrient water pollution in estuaries, keeping in mind any disproportionate impacts on marginalized ethnic/ racial groups (Cushing et al. 2018). This will drive oyster reef restoration and provide pressure to change the practices of polluters at the source.

\section{Advantages}

- For private property owners, Living Shorelines have been shown to cost four times less for annual maintenance while providing protection that results in half as much hurricane damage (Smith et al. 2017). 
- Nearly $40 \%$ of the United States populace resides in coastal bordering counties (NOAA's Office for Coastal Management 2021) which will benefit from shoreline stabilization.

- Increase food safety for all consumers, especially immunocompromised individuals.

- Cap and trade programs are a widely implemented market based solution to encourage particular behaviors (Zhang, Zhang, and Bi 2012; Boyce and Ash 2018). Here the benefits are twofold, enhancement of oyster reef restoration in spite of consumer-based profit and reduction of nutrient based water pollution.

\section{Disadvantages}

- Progress has been slow. Despite fifty-six years of work to restore oyster populations throughout the U.S., by 2018 only $4.5 \%$ of the known historic reef area was recovered across the U.S. Atlantic and Gulf coasts (Bersoza Hernández et al. 2018).

- Available rapid tests for shellfish pathogens are for clinical use only, so the development and production of rapid pathogen tests for consumers currently face technical and regulatory hurdles.

\section{ii. Recommendation 2: Establish international collaborations for restoration}

We propose that the Biden administration present an "Oyster Restoration Initiative" at the 2021 World Economic Forum (WEF) Annual Meeting in Singapore to restore 2.47 million acres (1 million hectares) of oyster reef habitat by 2035 . This nature-based solution to climate change would be a coastal counterpart to the Trillion Trees Initiative that was created by the WEF in January 2020. This oyster restoration goal can be achieved by providing publicity and resources to the Global Shellfish Rehab Network, which currently connects 123 project teams ("The Global Shellfish Rehab Network" 2021), and by gathering restoration commitments from nationstates. The network estimates that there are 5.8 million acres of "Currently Restorable Shellfish Habitat" worldwide ("The Global Shellfish Rehab Network" 2021), so the goal of 2.47 million acres restored would be a modest starting point.

\section{Advantages}

- Methods for oyster restoration, and their ecosystem benefits, are highly transferable between regions.
- International efforts magnify the carbon sequestration potential of oysters.

- Aligns with the UN's decade of "Ocean Science for Sustainable Development" and "Ecosystem Restoration” (“UN Decade on Restoration” 2019).

\section{Disadvantages}

- There is little precedent for incorporating oyster restoration into public policy.

- True accountability for voluntary international efforts is difficult to achieve.

iii. Recommendation 3: Revolutionize food production with restorative aquaculture

We recommend establishing restorative aquaculture programs that provide a sustainable food and income source to coastal communities, while enhancing domestic oyster restoration. Specifically, we recommend to:

1) Provide market incentives for oyster farms to incorporate sustainable practices, including seaweed farming. This could include facilitating the sale of seaweed as livestock feed to reduce GHG emissions in the food industry. To accelerate the adoption of seaweed as livestock feed, NOAA and the USDA should establish a program to buy seaweed from sustainable aquaculture farms and sell it at reduced prices to cattle farmers.

2) Shift subsidies away from agricultural sectors that are economically and ecologically unsustainable (Simon 2013) so that sustainable options like oysters can compete in a free market.

3) Establish vocational training programs at the high school and post-secondary levels to address labor shortages and provide skills for restorative aquaculture.

\section{Advantages}

- American consumers will have increased access to a low-carbon source of protein, with an abundance of health benefits (Gopakumar and Gopakumar 2020).

- GHG emissions from cattle farming can be drastically reduced (80-98\%) by incorporating seaweed into cattle diets (Machado et al. 2016; 2016; Roque et al. 2019; Kinley et al. 2020). 
- Oysters and seaweed reduce nutrient pollution (Stuchtey et al. 2020).

- Blue collar workers displaced from other industries may find aquaculture an attractive field of work.

\section{Disadvantages}

- Farmer participation and consumer acceptance are needed to realize the GHG reductions of seaweed-fed cattle.

- Entrenched special interests will not yield their subsidies without a political fight.

\section{References}

Baggett, Lesley.P., Sean P. Powers, Robert Brumbaugh, Loren D. Coen, B DeAngelis, Jennifer Greene, Boze Hancock, and Summer Morlock. 2014. "Oyster Habitat Restoration Monitoring and Assessment Handbook." Arlington, VA: The Nature Conservancy.

http://chnep.wateratlas.usf.edu/upload/docume nts/Oyster-Habitat-Restoration-Monitoring-AndAssessment-Handbook.pdf

Brumbaugh, Robert D., Michael W. Beck, Loren D. Coen, Leslie Craig, and Polly Hicks. 2006. "A Practitioners' Guide to the Design and Monitoring of Shellfish Restoration Projects: An Ecosystem Services Approach." Arlington, VA: The Nature Conservancy.

Bruner, David M., William L. Huth, David M. McEvoy, and O. Ashton Morgan. 2014. "Consumer Valuation of Food Safety: The Case of Postharvest Processed Oysters." Agricultural and Resource Economics Review; Durham 43 (2): 300-318.

CDC. 2020. "Oysters and Vibriosis." Centers for Disease Control and Prevention. June 26, 2020. https://www.cdc.gov/foodsafety/communicatio n/oysters-and-vibriosis.html.

Cushing, Lara, Dan Blaustein-Rejto, Madeline Wander, Manuel Pastor, James Sadd, Allen Zhu, and Rachel Morello-Frosch. 2018. "Carbon Trading, CoPollutants, and Environmental Equity: Evidence from California's Cap-and-Trade Program (20112015)." Edited by Jonathan Patz. PLOS Medicine 15 (7): e1002604. https://doi.org/10.1371/journal.pmed.1002604. Ermgassen, Philine S. E. zu, Jonathan H. Grabowski, Jonathan R. Gair, and Sean P. Powers. 2016. "Quantifying Fish and Mobile Invertebrate Production from a Threatened Nursery Habitat." Journal of Applied Ecology 53 (2): 596-606. https://doi.org/10.1111/1365-2664.12576.

\section{Policy recommendation}

The authors favor Recommendation 3 to revolutionize domestic food production via restorative aquaculture, as it bolsters wild oyster populations, creates year-round farming jobs, and reduces GHG emissions of land-based agriculture. As world economies recover from the COVID-19 pandemic, the present moment is a prime opportunity to "build back better" by investing in a blue economy with strong marine industries.

Fitzsimons, James A., Simon Branigan, Chris L. Gillies, Robert D. Brumbaugh, Jun Cheng, Bryan M. DeAngelis, Laura Geselbracht, et al. 2020. "Restoring Shellfish Reefs: Global Guidelines for Practitioners and Scientists." Conservation Science and Practice 2 (6): e198. https://doi.org/10.1111/csp2.198.

Fodrie, F. Joel, Antonio B. Rodriguez, Rachel K. Gittman, Jonathan H. Grabowski, Niels. L. Lindquist, Charles H. Peterson, Michael F. Piehler, and Justin T. Ridge. 2017. "Oyster Reefs as Carbon Sources and Sinks." Proceedings of the Royal Society B: Biological Sciences 284 (1859): 20170891. https://doi.org/10.1098/rspb.2017.0891.

Food and Drug Administration. 2019. "National Shellfish Sanitation Program (NSSP) Guide for the Control of Molluscan Shellfish: 2019 Revision." USA.

$\mathrm{Fu}$, Kaiyue, Yan Zheng, Juan Li, Yushen Liu, Bo Pang, Xiuling Song, Kun Xu, Juan Wang, and Chao Zhao. 2018. "Colorimetric Immunoassay for Rapid Detection of Vibrio Parahemolyticus Based on $\mathrm{Mn} 2+$ Mediates the Assembly of Gold Nanoparticles." Journal of Agricultural and Food Chemistry 66 (36): 9516-21. https://doi.org/10.1021/acs.jafc.8b02494.

Gerber, Pierre J., and Food and Agriculture Organization of the United Nations, eds. 2013. Tackling Climate Change through Livestock: A Global Assessment of Emissions and Mitigation Opportunities. Rome: Food and Agriculture Organization of the United Nations.

Gopakumar, K., and Balagopal Gopakumar. 2020. Health Foods from Ocean Animals. Milton, UNITED KINGDOM: Taylor \& Francis Group. http://ebookcentral.proquest.com/lib/rutgersebooks/detail.action?docID=6195992. 
Grabowski, Jonathan H., Robert D. Brumbaugh, Robert F. Conrad, Andrew G. Keeler, James J. Opaluch, Charles H. Peterson, Michael F. Piehler, Sean P. Powers, and Ashley R. Smyth. 2012. "Economic Valuation of Ecosystem Services Provided by Oyster Reefs." BioScience 62 (10): 900-909. https://doi.org/10.1525/bio.2012.62.10.10.

Gregalis, Kevan C., Matthew W. Johnson, and Sean P. Powers. 2009. "Restored Oyster Reef Location and Design Affect Responses of Resident and Transient Fish, Crab, and Shellfish Species in Mobile Bay, Alabama." Transactions of the American Fisheries Society 138 (2): 314-27. https://doi.org/10.1577/T08-041.1.

Ismail, Niveen S., Claudia E. Müller, Rachel R. Morgan, and Richard G. Luthy. 2014. "Uptake of Contaminants of Emerging Concern by the Bivalves Anodonta Californiensis and Corbicula Fluminea." Environmental Science \& Technology 48 (16): 9211-19. https://doi.org/10.1021/es5011576.

Kinley, Robert D., Gonzalo Martinez-Fernandez, Melissa K. Matthews, Rocky de Nys, Marie Magnusson, and Nigel W. Tomkins. 2020. "Mitigating the Carbon Footprint and Improving Productivity of Ruminant Livestock Agriculture Using a Red Seaweed." Journal of Cleaner Production 259 (June): 120836. https://doi.org/10.1016/i.jclepro.2020.120836.

La Peyre, Megan K., Kayla Serra, T. Andrew Joyner, and Austin Humphries. 2015. "Assessing Shoreline Exposure and Oyster Habitat Suitability Maximizes Potential Success for Sustainable Shoreline Protection Using Restored Oyster Reefs." PeerJ, October. http://dx.doi.org.proxy.libraries.rutgers.edu/10. 7717/peerj.1317.

Land, Lynton S. 2014. “Oysters' Impact on Water Quality in the Potomac River Estuary." Aquatic Geochemistry 20 (5): 465-66. https://doi.org/10.1007/s10498-014-9235-x.

Leonard, Dorothy, and Sandra Macfarlane. 2011. "Best Management Practices for Shellfish Restoration." Prepared for the ISSC Shellfish Restoration Committee.

http://www.sarasota.wateratlas.usf.edu/upload/ documents/BMPs-for-Shellfish-Restoration-ISSC2011.pdf.

Machado, Lorenna, Marie Magnusson, Nicholas A. Paul, Robert Kinley, Rocky de Nys, and Nigel Tomkins. 2016. "Dose-Response Effects of Asparagopsis Taxiformis and Oedogonium Sp. on in Vitro Fermentation and Methane Production." Journal of Applied Phycology 28 (2): 1443-52. https://doi.org/10.1007/s10811-015-0639-9.
McAfee, Dominic, and Sean D Connell. 2020. "The Global Fall and Rise of Oyster Reefs." Frontiers in Ecology and the Environment, December, fee.2291. https://doi.org/10.1002/fee.2291.

McCann, Michael. 2019. "Restoring Oysters to Urban Waters: Lessons Learned and Future Opportunities in NY/NJ Harbor." New York, NY: The Nature Conservancy.

Mumbles Oyster Company. 2021. "Native Oyster Network." 2021. https://nativeoysternetwork.org/portfolio/mum blesoyster/.

NOAA Office for Coastal Management. 2021. "High Tide Flooding." 2021. https://coast.noaa.gov/states/fastfacts/recurrent-tidal-flooding.html.

NOAA's Office for Coastal Management. 2021. "Economics and Demographics." 2021.

https://coast.noaa.gov/states/fastfacts/economics-and-demographics.html.

Parker, Matt, and Suzanne Bricker. 2020. "Sustainable Oyster Aquaculture, Water Quality Improvement, and Ecosystem Service Value Potential in Maryland Chesapeake Bay." Journal of Shellfish Research 39 (2): 269-81. https://doi.org/10.2983/035.039.0208.

Preston, Joanne, Celine Gamble, Alison Debney, Luke Helmer, Boze Hancock, and Philine zu Ermgassen. 2020. "European Native Oyster Habitat Restoration Handbook." London, UK: The Zoological Society of London, UK.

Ray, Nicholas E., Timothy J. Maguire, Alia N. Al-Haj, Maria C. Henning, and Robinson W. Fulweiler. 2019. "Low Greenhouse Gas Emissions from Oyster Aquaculture." Environmental Science \& Technology 53 (15): 9118-27. https://doi.org/10.1021/acs.est.9b02965.

Rodriguez, Antonio B., F. Joel Fodrie, Justin T. Ridge, Niels L. Lindquist, Ethan J. Theuerkauf, Sara E. Coleman, Jonathan H. Grabowski, et al. 2014. "Oyster Reefs Can Outpace Sea-Level Rise." Nature Climate Change 4 (6): 493-97. https://doi.org/10.1038/nclimate2216.

Roque, Breanna Michell, Charles Garrett Brooke, Joshua Ladau, Tamsen Polley, Lyndsey Jean Marsh, Negeen Najafi, Pramod Pandey, et al. 2019. "Effect of the Macroalgae Asparagopsis Taxiformis on Methane Production and Rumen Microbiome Assemblage." Animal Microbiome 1 (1): 3. https://doi.org/10.1186/s42523-019-0004-4. 
Schnitkey, Gary, Krista Swanson, Jonathan Coppess, Nick Paulson, and Carl Zulauf. 2020. "MFP and CFAP Payments, Corn and Soybean Uses, and Future Farm Profitability." (10):106. Farmdoc Daily. Department of Agricultural and Consumer Economics, University of Illinois at UrbanaChampaign.

https://farmdocdaily.illinois.edu/2020/06/mfpand-cfap-payments-corn-and-soybean-uses-andfuture-farm-profitability.html.

Simon, David Robinson. 2013. Meatonomics: How the Rigged Economics of Meat and Dairy Make You Consume Too Much-and How to Eat Better, Live Longer, and Spend Smarter. Conari Press.

Smith, Carter S., Rachel K. Gittman, Isabelle P. Neylan, Steven B. Scyphers, Joseph P. Morton, F. Joel Fodrie, Jonathan H. Grabowski, and Charles H. Peterson. 2017. "Hurricane Damage along Natural and Hardened Estuarine Shorelines: Using Homeowner Experiences to Promote Nature-Based Coastal Protection." Marine Policy 81 (July): 350-58. https://doi.org/10.1016/j.marpol.2017.04.013. Smith, Carter S., Morgan E. Rudd, Rachel K. Gittman, Emily C. Melvin, Virginia S. Patterson, Julianna J. Renzi, Emory H. Wellman, and Brian R. Silliman. 2020. "Coming to Terms With Living Shorelines: A Scoping Review of Novel Restoration Strategies for Shoreline Protection." Frontiers in Marine Science 7. https://doi.org/10.3389/fmars.2020.00434. Stuchtey, Martin R, Adrien Vincent, Andreas Merkl, Maximilian Bucher, Peter M Haugan, Jane Lubchenco, and Mari Elka Pangestu. 2020. "Ocean Solutions That Benefit People, Nature and the Economy." Washington, DC: World Resources Institute. www.oceanpanel.org/ocean-solutions.
"The Blue Carbon Initiative." 2019. The Blue Carbon Initiative. 2019. https://www.thebluecarboninitiative.org.

"The Global Shellfish Rehab Network." 2021. The Global Shellfish Rehab Network. 2021. https://shellfishrehab.net/.

"UN Decade on Restoration." 2019. UN Decade on Restoration. 2019. http://www.decadeonrestoration.org/node.

Walles, Brenda, João Salvador de Paiva, Bram C. van Prooijen, Tom Ysebaert, and Aad C. Smaal. 2015. "The Ecosystem Engineer Crassostrea Gigas Affects Tidal Flat Morphology Beyond the Boundary of Their Reef Structures." Estuaries and Coasts 38 (3): 941-50. https://doi.org/10.1007/s12237-014-9860-z.

$\mathrm{Xu}$, Feng, Saba Ilyas, Jeffrey A. Hall, Stephen H. Jones, Vaughn S. Cooper, and Cheryl A. Whistler. 2015. "Genetic Characterization of Clinical and Environmental Vibrio Parahaemolyticus from the Northeast USA Reveals Emerging Resident and Non-Indigenous Pathogen Lineages." Frontiers in Microbiology 6. https://doi.org/10.3389/fmicb.2015.00272.

Zhang, Yongliang, Bing Zhang, and Jun Bi. 2012. "Policy Conflict and the Feasibility of Water Pollution Trading Programs in the Tai Lake Basin, China." Environment and Planning C: Government and Policy 30 (3): 416-28. https://doi.org/10.1068/c11124

Heidi Yeh is a graduate student at Rutgers University, pursuing a $\mathrm{PhD}$ in Oceanography. Her research focuses on the oyster microbiome in the context of aquaculture and reef restoration. Heidi holds a B.A. from Barnard College of Columbia University and a M.S. from the University of Connecticut. She enjoys communicating science through food, and was drawn to oysters as a vehicle for connecting people to the environment.

Elizabeth Bouchard is a 1st year graduate student in the Ecology and Evolution Graduate Program at Rutgers University. She holds a BA in environmental science from Wheaton College (MA). Her research investigates the influence of the oyster aquaculture industry on the ecological relationship between horseshoe crabs and a threatened migratory shorebird species. Elizabeth is passionate about science communication. She strives to bridge the gap between scientists, industry, and policymakers. 
Austin Grubb is a 4th year Ph.D. candidate in Oceanography at Rutgers University. His research focuses on the costs and benefits of calcification in a group of marine phytoplankton known as coccolithophores. Austin holds a B.S. in Biology and a B.A. in Spanish from Susquehanna University, Selinsgrove, PA. He is interested in policy solutions to mitigate environmental issues, particularly around large and complex issues like climate change.

Hunter Lanovoi is a 3rd year Ph.D. candidate in the department of Pharmacology, Physiology, and Neuroscience at Rutgers New Jersey Medical school. His dissertation work focuses on how animals integrate external social cues and internal bodily cues to support social-emotional behaviors. Hunter holds an A.B. from Rollins College, Winter Park FL. He is passionate about enhancing communication between scientists and the public and engaging in discourse on healthcare, mental health, and basic research policy.

\section{Acknowledgements}

The authors would like to acknowledge Science Policy Advocacy at Rutgers (SPAR) for catalyzing the work of this team. 